\title{
Pengamatan dan Pemetaan Penyakit Busuk Pangkal Batang di Perkebunan Kelapa Sawit Menggunakan Unmanned Aerial Vehicle (UAV) dan Kamera Multispektral
}

\author{
Surveillance and Mapping of Basal Stem Rot Disease in Oil Palm \\ Plantation Using Unmanned Aerial Vehicle (UAV) \\ and Multispectral Camera
}

\author{
Heri Santoso \\ Pusat Penelitian Kelapa Sawit, Medan 20158
}

\begin{abstract}
ABSTRAK
Penyakit busuk pangkal batang (BPB) yang disebabkan oleh jamur Ganoderma boninensis masih menjadi penyakit utama pada perkebunan kelapa sawit baik di Indonesia maupun Malaysia. Identifikasi dan monitoring penyakit BSR banyak dilakukan menggunakan teknologi penginderaan jauh. Pemanfaatan citra (image) dari satelit dalam kajian penginderaan jauh terutama untuk studi vegetasi di daerah tropis sering terkendala dengan adanya awan. Drone dan unmanned aerial vehicle (UAV) merupakan wahana yang sesuai untuk dimanfaatkan dalam antisipasi adanya awan tersebut. Penggunaan machine learning random forest $(\mathrm{RF})$ dan citra satelit mampu mengidentifikasi dan memonitor sebaran tanaman kelapa sawit sehat dan terinfeksi penyakit BPB dengan tingkat akurasi yang baik. Penelitian ini bertujuan untuk mengidentifikasi penyakit BPB dan memetakan distribusi secara individu tanaman yang sehat dan terinfeksi penyakit BPB menggunakan image atau hasil perekaman dengan kamera multispektral dan UAV serta RF sebagai metode klasifikasinya. Hasil kajian menunjukkan bahwa perekaman dengan UAV bebas dari awan tetapi terpengaruh oleh bayangan awan. Hasil klasifikasi dengan RF dan pemetaan sebaran tanaman terinfeksi penyakit BPB dipengaruhi oleh adanya tutupan bayangan awan. Akurasi klasifikasi tanaman yang sehat dan terinfeksi penyakit BPB dengan RF yang tertinggi sebesar $79.49 \%$. Kalibrator pantulan (reflectance), konversi digital number ke reflectance, dan implementasi model untuk pemetaan tanaman sehat dan terinfeksi penyakit BPB perlu dilakukan pada areal yang tidak terpengaruh dan terpengaruh oleh bayangan awan. Selain itu, pengambilan gambar (pemotretan) perlu mempertimbangkan adanya awan di wilayah pemotretan.
\end{abstract}

Kata kunci: Ganoderma, machine learning, remote sensing, random forest

\begin{abstract}
Basal stem rot (BSR) disease caused by Ganoderma boninensis is still a major disease in oil palm plantations both in Indonesia and Malaysia. In some countries, remote sensing approach has been used for monitoring BSR in oil palm plantation. However, the utilization of satellite imagery in remote sensing especially in vegetation study on the tropical region was often limited by cloud cover. A drone or unmanned aerial vehicle (UAV) utilization is the best way to deal with cloud cover in the tropic region. Machine learning of random forest (RF) and satellite imagery used in the BSR study produced good accuracy. This research was aimed to identify and monitor the BSR infection on individual oil palm
\end{abstract}

*Alamat penulis korespondensi: Pusat Penelitian Kelapa Sawit. Jalan Brigjen Katamso 51 Kampung Baru, Medan 20158.

Tel: 061-7862477, Faks: 061-7862488, surel: hs_jmp@yahoo.com. 
trees using an UAV and multispectral camera and RF classification. The results showed that the data acquired from UAV was affected by cloud shadows. The RF classification of healthy and infected oil palm trees by BSR disease and the spreading map of BSR infection was affected by cloud shadows. The highest accuracy of healthy and infected oil palm by BSR was $79.49 \%$. Reflectance calibrator, digital to reflectance conversion, and model implications to build spreading map of BSR infection need to be conducted both on the clear area and the cloud shadow-covered area. Moreover, the UAV-based data should be considering the cloud view on the coverage area.

Key words: Ganoderma, machine learning, remote sensing, random forest

\section{PENDAHULUAN}

Penggunaan teknik remote sensing (penginderaan jauh) baik menggunakan spectroradiometer maupun citra satelit untuk mendeteksi dan memetakan tanaman kelapa sawit yang menunjukkan gejala busuk pangkal batang (BPB) karena infeksi Ganoderma boninensis sudah banyak dilakukan oleh beberapa peneliti (Shafri and Hamdan 2009; Lelong et al. 2010; Shafri et al. 2011; Liaghat et al. 2014; Santoso et al. 2011, 2017, 2018). Obyek kajian tentang penyakit BPB tersebut (Ling-chie et al. 2012; Susanto et al. 2013) masih menjadi penyakit utama dan belum ada penanganan yang efektif baik pada perkebunan kelapa sawit di Indonesia maupun Malaysia (Hushiarian et al. 2013; Priwiratama et al. 2014).

Kendala yang sering dihadapi dalam menggunakan citra satelit di daerah tropis ialah tutupan awan. Drone dan unmanned aerial vehicle (UAV) saat ini sudah banyak dimanfaatkan untuk segala bidang baik hobi maupun penunjang pekerjaan mengingat penggunaannya tidak terpengaruh oleh tutupan awan dan waktu perekaman yang dapat disesuaikan dengan kebutuhan. Di perkebunan kelapa sawit, drone dan UAV digunakan untuk pemetaan areal kebun dan palm counting (penghitungan jumlah pohon). Pengoptimalan pemanfaatan drone dan UAV di perkebunan kelapa sawit dapat dilakukan dengan mengganti kamera digital (full color: $\mathrm{RGB}=$ red-green-blue) dengan kamera multispektral.

Pemanfaatan image atau hasil perekaman menggunakan kamera multispektral dari wahana satelit dapat digunakan untuk deteksi dan pemetaan tanaman kelapa sawit yang sehat dan tanaman yang terserang penyakit BPB (Santoso et al. 2011; 2017). Kajian identifikasi dan pemetaan tanaman yang sehat dan terserang penyakit BPB dengan memanfaatkan citra (image) dari kamera multispektral pada wahana drone atau UAV masih jarang dilakukan. Hasil penelitian Wiratmoko et al. (2018) yang menggunakan kamera multispektral (3 band) dapat mengidentifikasi penyakit BPB dengan pendekatan indeks vegetasi dan tingkat akurasi $85 \%$. Penelitian tersebut menggunakan formula indeks vegetasi untuk identifikasi penyakit BPB, namun belum dilakukan identifikasi dan pemetaan secara individu ke areal yang lain, sehingga belum diketahui distribusi tanaman yang sehat dan terinfeksi penyakit BPB tersebut.

Penelitian Santoso et al. (2017) menggunakan pendekatan rata-rata nilai piksel kanopi kelapa sawit dari citra QuickBird dengan metode klasifikasi menggunakan machine learning algorithms (random forest) RF) mampu menghasilkan tingkat akurasi 91\% dan menerapkan model klasifikasi yang didapat untuk memetakan distribusi individu tanaman yang sehat dan terinfeksi penyakit BPB di area studi (49 793 tanaman). Berdasarkan hasil penelitian sebelumnya tentang pemanfaatan penginderaan jauh untuk kajian penyakit BPB di perkebunan kelapa sawit, penelitian ini bertujuan untuk mengidentifikasi penyakit BPB dan memetakan distribusi secara individu tanaman yang sehat dan terinfeksi penyakit BPB menggunakan image atau hasil perekaman dengan kamera multispektral dan UAV serta machine learning algorithms (random forest/ RF) sebagai metode klasifikasinya. 


\section{BAHAN DAN METODE}

Penelitian dilakukan di Kebun Percobaan Aek Pancur, Pusat Penelitian Kelapa Sawit yang terletak di Tanjung Morawa, Deli Serdang, Sumatera Utara. Pengambilan sampel tanaman kelapa sawit dan perekaman image menggunakan UAV dan kamera multispektral dilakukan pada tanggal 1 Agustus 2019.

\section{UAV dan Kamera Multispectral}

Wahana (awak) yang digunakan berupa UAV model T-tail vol tron dengan badan pesawat terbuat dari bahan expanded polyolefin (EPO) dengan penguat rangka dari bahan serat karbon. Pesawat ini dilengkapi perangkat telemetri dengan kemampuan jangkauan mencapai $15 \mathrm{~km}$. Lebar pesawat $1880 \mathrm{~mm}$ dengan kapasitas baterai 5500 $\mathrm{MaH}$, kemampuan terbang 35-40 menit, metode take off dengan diluncurkan manual, metode perekaman kamera diatur otomatis berdasarkan jarak (autoshutter by distance) dan tinggi terbang sampai $3000 \mathrm{~m}$. Sedangkan kamera yang digunakan ialah Mapir Survey 3, yaitu sensor kamera Sony Exmox R IMX117 dengan 3 filter untuk menghasilkan 3 band/saluran (multispectral) dalam satu unit kamera serta resolusi gambar 12 megapiksel $(4000 \times 300 \mathrm{px})$ dan berat hanya $50 \mathrm{~g}$ tanpa baterai atau $76 \mathrm{~g}$ termasuk baterai. Optik lensa dengan spesifikasi berupa $87^{\circ} \mathrm{HFOV}(19 \mathrm{~mm}) \mathrm{f} / 2,8$ aperture, $-1 \%$ low distortion glass lens (non-fisheye). Ground sample distance (GSD) sebesar $5.5 \mathrm{~cm} / \mathrm{px}$ pada tinggi terbang $120 \mathrm{~m}$ di atas permukaan tanah. Tiga band tersebut ialah merah $(\mathrm{red} / \mathrm{R})$ dengan panjang gelombang $660 \mathrm{~nm}$, hijau (green $/ G)$ dengan panjang gelombang 550 $\mathrm{nm}$, dan inframerah dekat (near infrared/ NIR) dengan panjang gelombang $850 \mathrm{~nm}$. Jenis GPS/GNSS di eksternal unit kamera berupa u-blox UBX-G7020-KT (https://www. mapir.camera/collections/survey $3 /$ products/ survey $3 \mathrm{w}$-camera-red-green-nir-rgn-ndvi).

Pengaturan UAV dan kamera multispectral ialah overlap antarjalur terbang sebesar $80 \%$ dan di dalam jalur $75 \%$, tinggi terbang $200 \mathrm{~m}$ di atas permukaan tanah, panjang jalur terbang $29.71 \mathrm{~km}$ dengan lama terbang 38 menit, dan waktu perekaman pukul 15:58-16:36 WIB. Sebelum mulai misi terbang dilakukan perekaman calibration reflectance target (CRT) yang akan digunakan untuk kalibrasi digital number (DN) hasil perekaman (image) kenilai pantulan. CRT merupakan kelengkapan dari kamera Mapir yang dilengkapi dengan software pengkonversi nilai DN ke nilai pantulan, yaitu Mapir camera control (MCC) (https://www.mapir.camera/pages/ calibrating-images-in-mapir-camera-controlapplication). Penggabungan (mosaic) image hasil perekaman dilakukan menggunakan program Agisoft Metashape trial license.

\section{Survei Lapangan untuk Pengumpulan Data Tanaman Kelapa Sawit}

Survei lapangan pengumpulan data tanaman kelapa sawit yang sehat dan terinfeksi penyakit BSR dilakukan pada 1 Agustus 2019 pada tanaman kelapa sawit tahun tanam 2002 sebanyak 478 pohon sawit. Hasil identifikasi terhadap 478 pohon sawit menunjukkan 165 pohon tergolong dalam kondisi terinfeksi penyakit BPB dan 313 pohon sawit tergolong sehat. Kriteria yang digunakan dalam identifikasi tanaman yang terinfeksi penyakit BPB ialah tajuk tanaman tidak membuka $>3$ pelepah, daun menguning dan mengering, patah pelepah (frond fracture), adanya tubuh buah jamur di batang, pangkal batang busuk atau berlobang.

\section{Analisis Data dan Klasifikasi}

Hasil mosaic image perekaman dengan UAV dan kamera Mapir menunjukkan ukuran piksel $10 \times 10 \mathrm{~cm}$, untuk analisis dan klasifikasi berdasarkan nilai piksel terlalu besar. Jika lebar kanopi sawit sekitar $8 \mathrm{~m}$, maka terdapat 80 piksel dalam satu kanopi sawit. Untuk memberikan pengaruh ukuran piksel terhadap akurasi klasifikasi maka dilakukan resize ukuran piksel, yaitu $0.5 ; 1.5$; dan $2.0 \mathrm{~m}$. Ukuran piksel tersebut mempertimbangkan hasil penelitian Santoso et al. (2017) yang menggunakan image Quickbird dengan resolusi spasial $2.54 \mathrm{~m}$ dan mampu mengklasfikasi tanaman sehat dan terinfeksi penyakit BSR dengan total akurasi $91 \%$. 
Titik-titik pengamatan 478 pohon sawit dikonversi ke poligon kotak berukuran $5 \mathrm{~m}$ dengan mempertimbangkan kanopi bagian tengah tanaman kelapa sawit. Ekstraksi nilai piksel dilakukan dengan menghitung nilai rata-rata piksel dalam poligon setiap band. Konversi dan ekstraksi nilai piksel dilakukan menggunakan software R. Nilai piksel setiap band akan digunakan sebagai variabel dalam klasifikasi tanaman sehat dan terinfeksi penyakit BPB. Klasifikasi dilakukan menggunakan machine learning random forest (RF) yang didasarkan pada hasil penelitian Santoso et al. (2017), kemudian data dibagi dua, yaitu training data sebesar $75 \%$ dan $25 \%$ testing data (Liaghat et al. 2014). Training data diperlukan untuk membangun model dan testing data untuk mengukur tingkat akurasi klasifikasi. Akurasi klasifikasi diukur menggunakan confusion matrix dan nilai kappa (Santoso et al. 2017; 2018).

\section{Pemetaan Sebaran Tanaman Terinfeksi Penyakit BPB}

Pemetaan sebaran tanaman sehat dan terinfeksi penyakit BPB dilakukan untuk mengetahui sebaran infeksi penyakit BPB dengan melakukan sampling area di dalam areal perekaman seluas 37.2 Ha. Tanaman kelapa sawit pada areal seluas $37.2 \mathrm{Ha}$ diidentifikasi sebagai titik dan dikonversi ke poligon yang selanjutnya dilakukan ekstraksi nilai piksel setiap kanopi tanaman kelapa sawit. Model terbaik klasifikasi akan digunakan untuk memetakan sebaran tanaman terinfeksi penyakit BPB.

\section{HASIL}

Areal kajian mempunyai topografi relatif datar dan merupakan areal endemik infeksi penyakit BSR. Pengambilan data dengan UAV dan kamera Mapir pada pukul 15:58-16:36 WIB memberikan penampakan sebagian areal terdapat bayangan awan. Areal yang memiliki bayangan awan menunjukkan areal yang agak gelap dibandingkan dengan areal yang tidak mengandung bayangan awan. Hasil mosaic image perekaman dengan UAV dan kamera Mapir dapat dilihat pada Gambar 1. Resize pixel image hasil perekaman beserta keterangan image-nya dapat dilihat pada Gambar 2. Semakin kecil ukuran piksel, image mempunyai ukuran penyimpanan yang

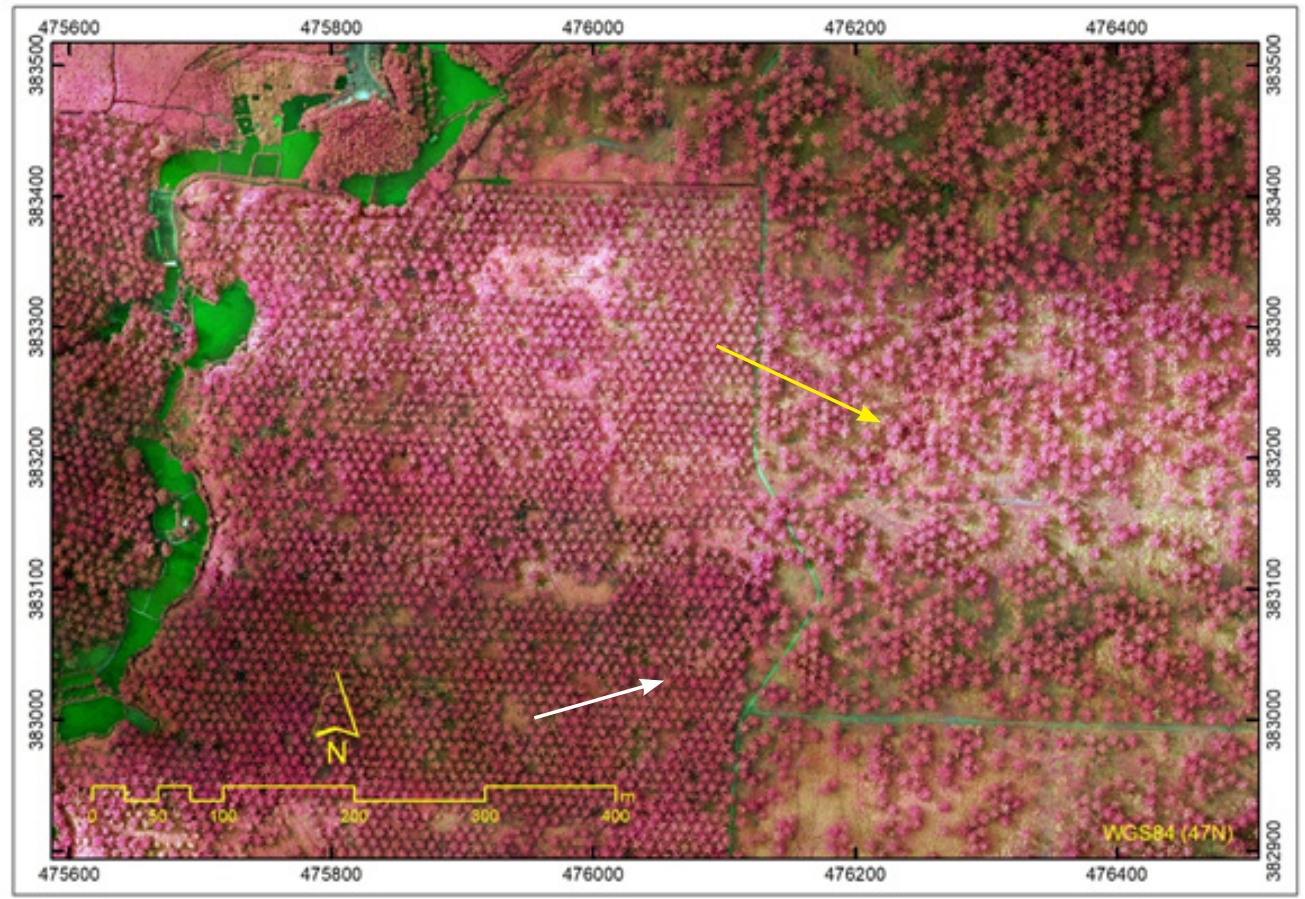

Gambar 1 Hasil mosaik di sebagian areal kajian. Panah kuning menunjukkan areal yang tidak ada pengaruh bayangan awan dan panah putih menunjukkan areal dengan pengaruh bayangan awan. 
a

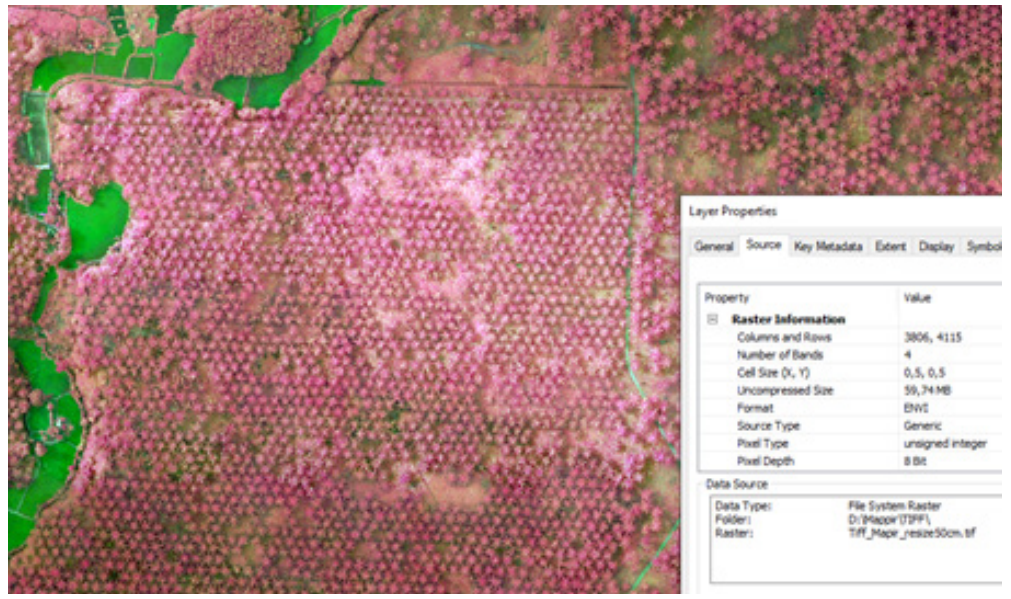

b

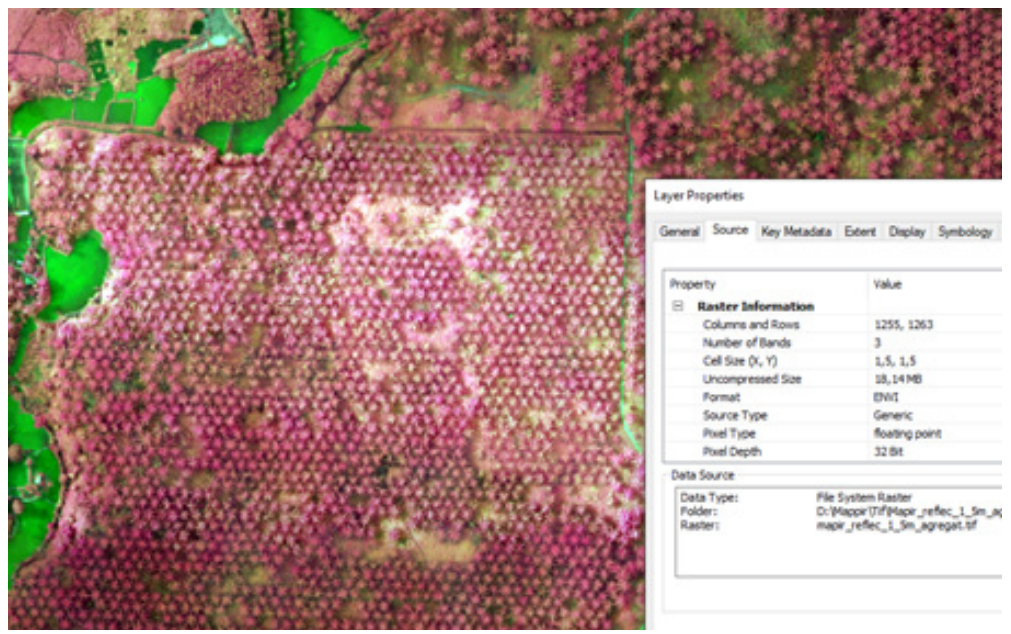

$\mathrm{c}$

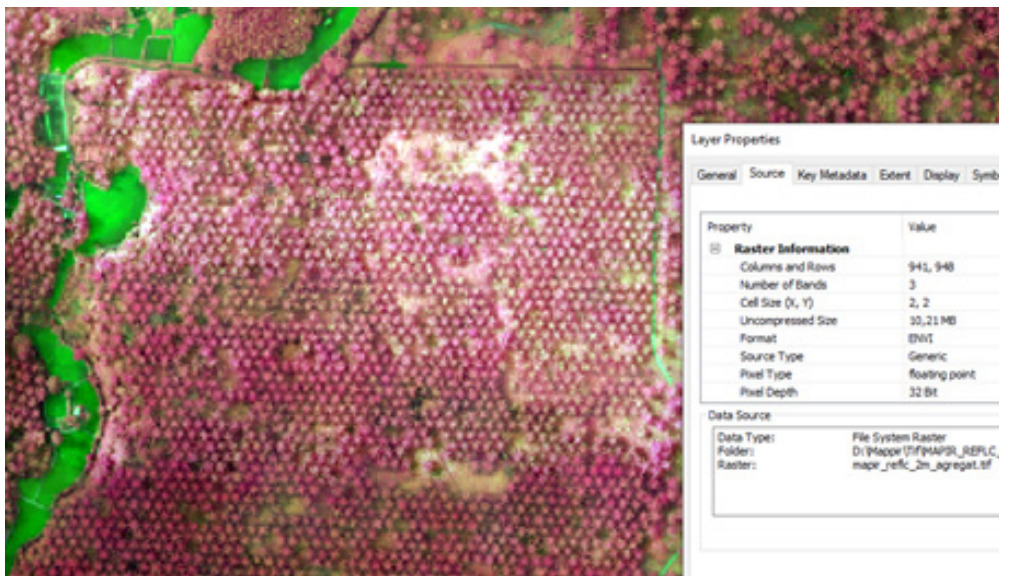

Gambar 2 Hasil resize image a, 0.5 m; b, 1.5 m; dan c, 2.0 m.

semakin kecil dan mempunyai penampakan bentuk kanopi yang cenderung lebih bulat. Pada image dengan ukuran piksel 0.5 dan $1.5 \mathrm{~m}$ bentuk kanopi dengan ujungnya yang runcing masih bisa dilihat. Karakteristik nilai pantulan masing-masing band pada tiga image hasil resize pixel dapat dilihat di Gambar 3. Karakteristik band 1, 2, dan 3 mempunyai kecenderungan yang relatif agak berbeda polapola pemantulannya pada tanaman sehat dan sakit antar-image hasil resize pixel $0.5 ; 1.5$; dan $2.0 \mathrm{~m}$. Pola kecenderungan nilai pantulan antara tanaman sehat dan sakit tersebut akan memengaruhi akurasi klasifikasi tanaman sehat dan sakit. Sedangkan scatterplot nilai pantulan tanaman sehat dan sakit pada Gambar 3 menunjukkan saling tumpang tindih atau nilai pantulan antara tanaman sehat dan sakit relatif sulit dibedakan. 

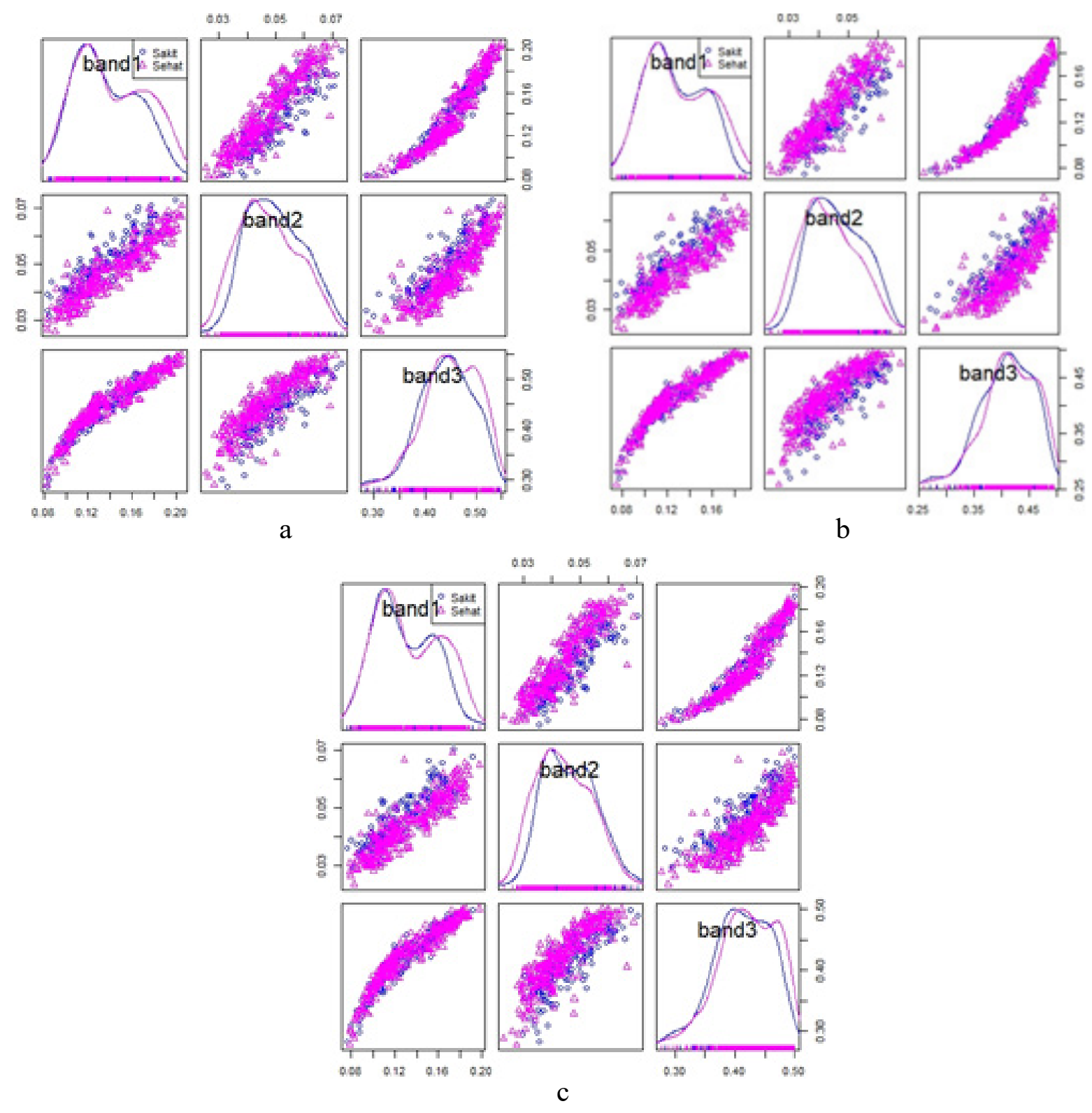

Gambar 3 Matrik scatterplot nilai pantulan tanaman sakit dan sehat pada masing-masing band di-resize image $0.5 \mathrm{~m}$ (a); $1.5 \mathrm{~m}$ (b); dan $2.0 \mathrm{~m}$ (c).

\section{Akurasi Klasifikasi}

Hasil klasifikasi tanaman sehat dan sakit menggunakan RF menunjukkan akurasi tertinggi sebesar $73.95 \%$ pada resize image $2.0 \mathrm{~m}$ dan akurasi sebesar $68.91 \%$ pada image hasil resize pixel 0.5 dan $1.5 \mathrm{~m}$ (Tabel 1). Nilai kappa tergolong cukup sekitar $0.25-0.37$ (Viera and Garrett 2005). Hasil klasifikasi menunjukkan bahwa dengan melakukan resize pixel pada image dari $10 \times 10 \mathrm{~cm}$ ke $200 \times 200 \mathrm{~cm}$ memberikan akurasi yang lebih tinggi dibandingkan dengan image berukuran piksel 0.5 dan $1.5 \mathrm{~m}$ (Tabel 1). Metode pixel aggregate pada proses resize pixel memberikan kontribusi dalam meningkatkan akurasi klasifikasi. Metode ini merupakan nilai ratarata yang dalam perhitungannya melibatkan piksel-piksel dalam ukuran piksel yang baru dengan mempertimbangkan pembobotan kontribusi piksel tersebut dalam ukuran piksel yang baru (ENVI 2014).

Gambar 1 menunjukkan hasil perekaman yang dipengaruhi oleh bayangan awan. Untuk mengetahui pengaruh bayangan awan terhadap akurasi klasifikasi, maka dilakukan analisis klasifikasi yang melibatkan titiktitik sampel yang berada di luar pengaruh bayangan awan tersebut. Sebanyak 158 
tanaman yang terdiri atas 52 tanaman terinfeksi penyakit BPB dan 106 tanaman sehat digunakan untuk klasifikasi dengan RF pada image hasil resize pixel $2.0 \mathrm{~m}$. Hasil klasifikasi menunjukkan peningkatan akurasi klasifikasi menjadi $79.49 \%$ dengan nilai kappa 0.48 (tergolong menengah) serta detil hasil klasifikasi ditunjukkan pada Tabel 2. Bayangan awan akan mempengaruhi nilai pantulan tanaman kelapa sawit yang terekam dalam sensor Mapir sehingga akan berdampak pada hasil klasifikasi yang mempertimbangkan nilai pantulan masing-masing band.

Pemetaan Sebaran Tanaman Kelapa Sawit Terinfeksi Penyakit BPB

Pemetaan sebaran tanaman kelapa sawit yang terinfeksi penyakit BPB dengan model klasifikasi machine leaning RF dilakukan pada areal seluas $37.2 \mathrm{Ha}$ di-resize image $2.0 \mathrm{~m}$. Jumlah tanaman pada areal seluas $37.2 \mathrm{Ha}$ ialah 3442 pohon. Hasil pemetaan sebaran tanaman kelapa sawit yang sehat dan terinfeksi penyakit BPB dengan model RF disajikan pada Gambar 4. Penyebaran tanaman kelapa sawit sehat dan terinfeksi penyakit BPB yang menggunakan model RF pada sampel tanaman yang bebas dari bayangan awan ditunjukkan pada Gambar 5. Penghitungan jumlah tanaman yang sehat dan terinfeksi penyakit BPB pada Gambar 4 berturut-turut ialah 2216 (64.38\%) dan 1226 (35.62\%) pohon. Sedangkan pada Gambar 5 menunjukkan tanaman yang sehat sebanyak 2294 (66.65\%) pohon dan tanaman yang terinfeksi penyakit BSR sebanyak 1148 (33.35\%) pohon. Perbedaan tanaman yang terinfeksi penyakit BSR pada Gambar 5 ialah sebanyak 78 tanaman lebih sedikit dibandingkan dengan Gambar 4 (Tabel 3).

\section{PEMBAHASAN}

Identifikasi dan pemetaan tanaman sehat dan terinfeksi penyakit BPB diperlukan untuk

Tabel 1 Hasil klasifikasi tanaman sehat dan sakit pada masing-masing resize pixel dengan RF

\begin{tabular}{|c|c|c|c|c|c|c|c|c|c|}
\hline \multirow{2}{*}{ Model aktual } & \multicolumn{3}{|c|}{ RF $0.5 \mathrm{~m}$} & \multicolumn{3}{|c|}{$\mathrm{RF} 1.5 \mathrm{~m}$} & \multicolumn{3}{|c|}{ RF $2.0 \mathrm{~m}$} \\
\hline & Sehat & Sakit & All & Sehat & Sakit & All & Sehat & Sakit & All \\
\hline Sehat & 67 & 11 & 78 & 64 & 14 & 78 & 70 & 8 & 78 \\
\hline Sakit & 26 & 15 & 41 & 23 & 18 & 41 & 23 & 18 & 41 \\
\hline All & 93 & 26 & 119 & 87 & 32 & 119 & 93 & 26 & 119 \\
\hline $\mathrm{PA}(\%)$ & 72.04 & 57.69 & & 73.56 & 56.25 & & 75.27 & 69.23 & \\
\hline UA (\%) & 85.90 & 36.59 & & 82.05 & 43.90 & & 89.74 & 43.90 & \\
\hline Akurasi pemetaan (\%) & 64.42 & 28.85 & & 63.37 & 32.73 & & 69.31 & 36.73 & \\
\hline $\mathrm{OA}(\%)$ & 68.91 & & & 68.91 & & & 73.95 & & \\
\hline Карра & 0.25 & & & 0.27 & & & 0.37 & & \\
\hline
\end{tabular}

Ket: $\mathrm{PA}=$ producer accuracy; $\mathrm{UA}=$ user accuracy; $\mathrm{OA}=$ overall accuracy.

Tabel 2 Hasil klasifikasi pada tanaman sehat dan sakit dengan RF pada sampel tanaman tidak terkena bayangan awan dan resize image $2.0 \mathrm{~m}$

\begin{tabular}{lccc}
\hline \multirow{2}{*}{ Model aktual } & \multicolumn{3}{c}{ RF } \\
\cline { 2 - 4 } & Sehat & Sakit & All \\
\hline Sehat & 25 & 1 & 26 \\
Sakit & 7 & 6 & 13 \\
All & 32 & 7 & 39 \\
PA (\%) & 78.13 & 85.71 & \\
UA (\%) & 96.15 & 46.15 & \\
Akurasi pemetaan (\%) & 75.76 & 42.86 & \\
OA (\%) & & 79.49 & \\
Kappa & & 0.48 & \\
\hline
\end{tabular}

Ket: $\mathrm{PA}=$ producer accuracy; $\mathrm{UA}=$ user accuracy; $\mathrm{OA}=$ overall accuracy. 


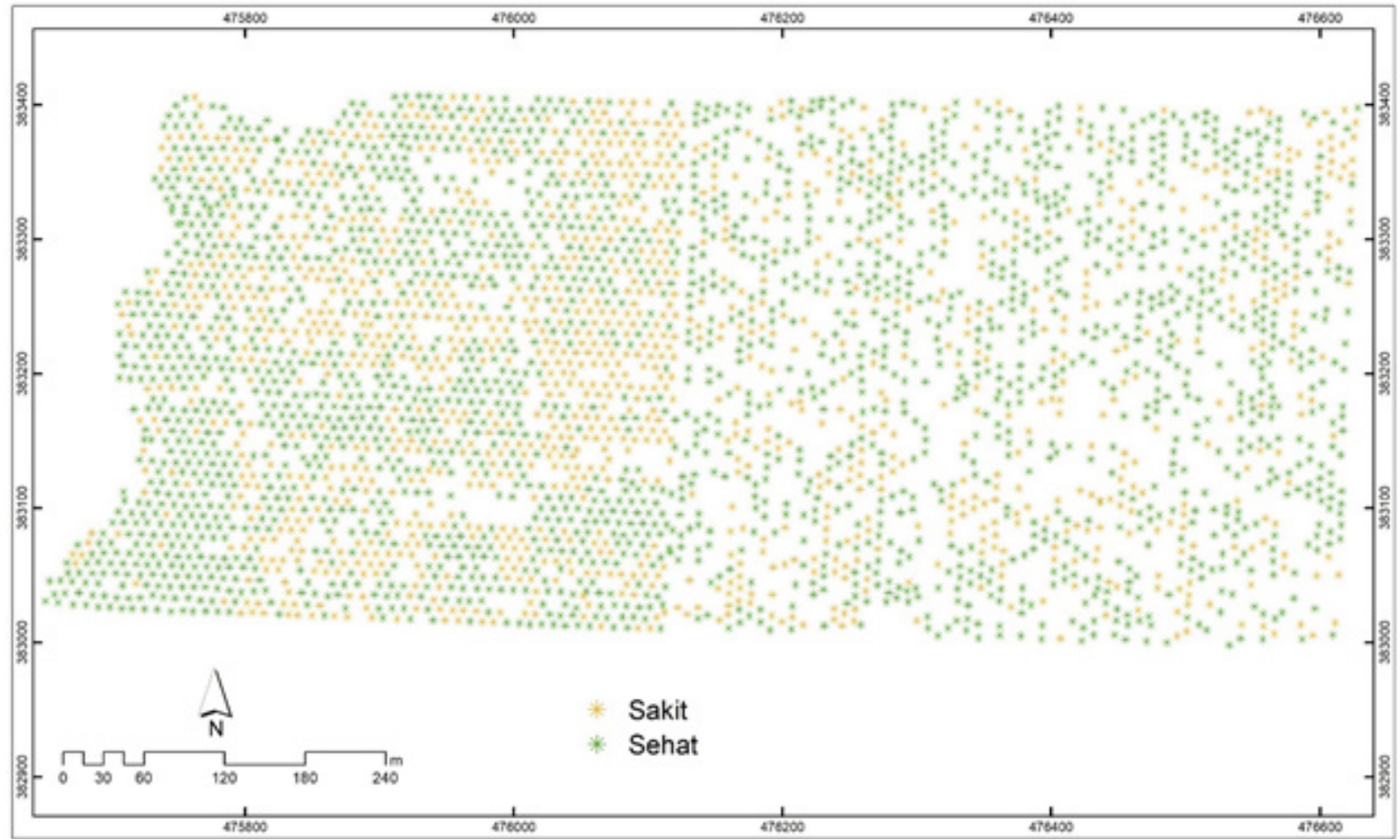

Gambar 4 Sebaran tanaman kelapa sawit yang terinfeksi penyakit BPB menggunakan model RF dari seluruh data.

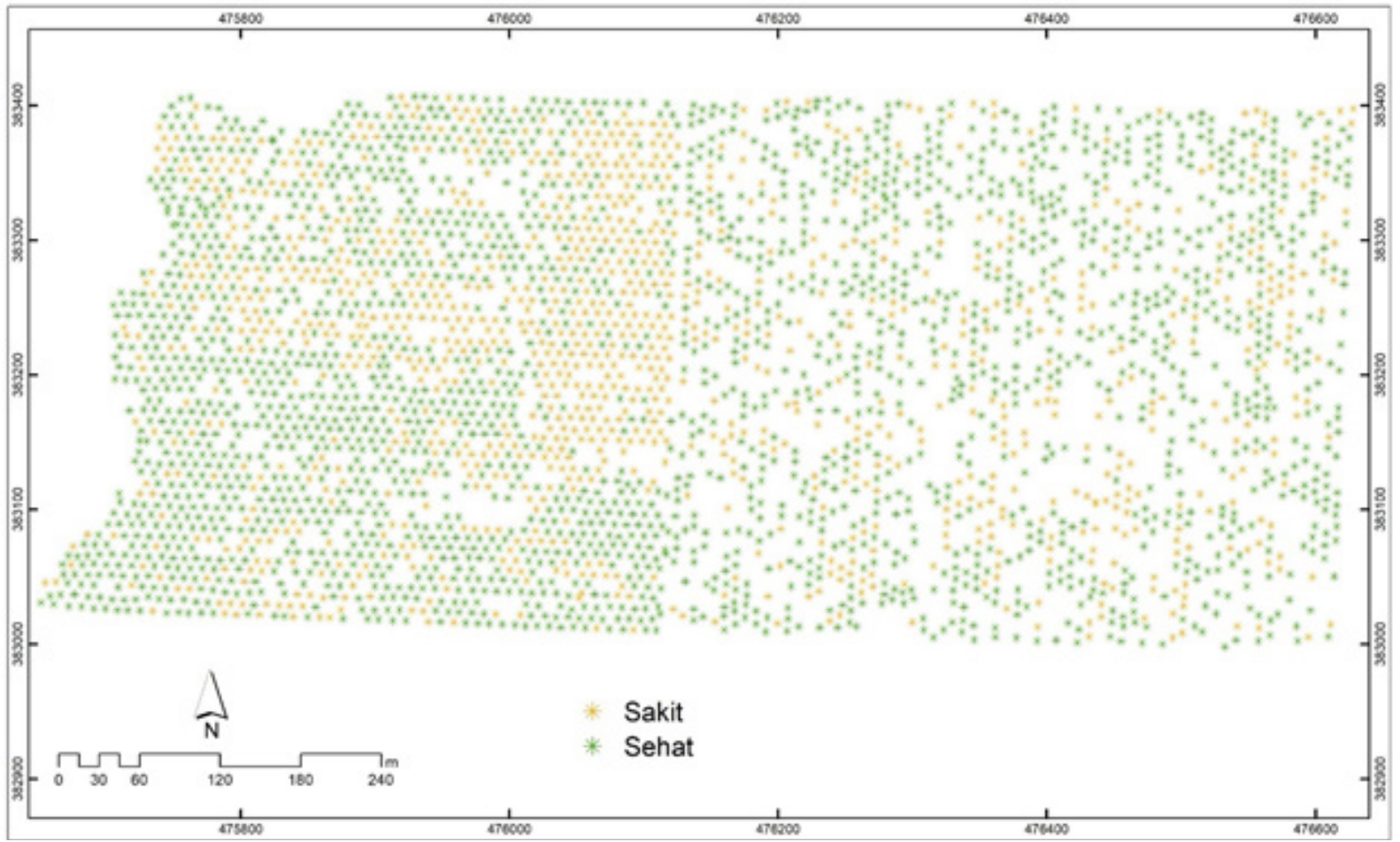

Gambar 5 Sebaran tanaman kelapa sawit yang terinfeksi penyakit BPB menggunakan model RF dari sampel tanaman pada areal bebas bayangan awan.

monitoring perkembangan penyebaran infeksi penyakit BPB, estimasi dampak penurunan produktivitas, kemungkinan penanganan untuk memperpanjang umur tanaman, dan proyeksi kapan harus dilakukan penanaman kembali. Hasil identifikasi dan pemetaan sebaran tanaman kelapa sawit sehat dan terinfeksi penyakit BSR pada penelitian ini 
Tabel 3 Perbedaan sebaran tanaman kelapa sawit sehat dan terinfeksi penyakit BSR

\begin{tabular}{ccrrrr}
\hline \multirow{2}{*}{ Kelas } & \multicolumn{2}{c}{ All data } & & \multicolumn{2}{c}{ Sebagian data } \\
\cline { 2 - 3 } \cline { 5 - 6 } & Non bayangan awan & Bayangan awan & & Non bayangan awan & Bayangan awan \\
\hline Sehat & 694 & 1519 & & 625 & 668 \\
Sakit & 386 & 840 & & 456 & 691 \\
\hline
\end{tabular}

Ket: All data $=$ model dibangun menggunakan seluruh data; sebagian data $=$ model dibangun menggunakan data pada areal yang tidak tertutup bayangan awan.

yang menggunakan kamera multispektral tiga band menunjukkan adanya potensi untuk dapat dimanfaatkan dan ditingkatkan akurasinya. Akurasi klasifikasi dengan machine learning RF pada penelitian ini memberikan hasil yang berbeda terkait dengan ukuran piksel dan adanya pengaruh bayangan awan.

Nilai piksel yang digunakan dalam klasifikasi di penelitian ini merupakan nilai rata-rata dari piksel-piksel yang ada di kanopi tanaman. Poligon segiempat (square) digunakan untuk menghitung rata-rata nilai piksel dari piksel-piksel yang ada di dalam poligon tersebut. Resize pixel image dengan metode pixel aggregate memberikan pengaruh dalam peningkatan akurasi klasifikasi karena nilai piksel pada image baru dari proses resize mempertimbangkan nilai piksel sekitarnya yang masuk dalam ukuran piksel yang baru dengan pembobotan sesuai dengan porsi bagian piksel yang masuk dalam ukuran piksel yang baru. Beberapa penelitian yang melakukan resize pixel image dan memberikan peningkatan akurasi interpretasi antara lain ialah Ming et al. (2011); dan McCloy dan Bøcher (2007).

Pemilihan wahana UAV untuk akuisisi data di daerah tropis yang sering tertutup awan merupakan solusi dalam bidang penginderaan jauh, namun masih ada bayangan awan yang dapat mengganggu kualitas image. Kajian yang tidak didasarkan pada nilai piksel, bayangan awan tidak menjadi hambatan karena secara visual obyek sawit masih dapat dikenali dengan tingkat kecerahan image (brightness) yang lebih rendah dibandingkan dengan obyek yang tidak tertutup bayangan awan. Pencahayaan, bayangan awan, dan bayangan obyek yang tinggi merupakan faktor yang harus diperhatikan dalam penggunaan UAV untuk kajian penginderaan jauh (Yao et al. 2019). Piksel yang ternaungi oleh bayangan awan tidak dapat dilakukan analisis menggunakan parameter yang sama pada areal yang tidak terpengaruh oleh bayangan awan. Hal tersebut dikarenakan nilai pantulan yang direkam sensor dipengaruhi awan. Cahaya matahari akan dihamburkan oleh awan dan sebagian akan sampai ke kanopi vegetasi dengan intensitas yang lebih kecil (Imai et al. 2019). Hal ini sejalan dengan kajian hasil klasifikasi dengan data pada areal yang tidak terpengaruh bayangan awan memberikan akurasi yang meningkat. Image yang direkam dengan UAV memberikan gambaran obyek tanaman kelapa sawit yang masih dapat dianalisis dibandingkan dengan hasil pemotretan satelit dengan obyek tanaman kelapa sawit tertutup oleh awan. Untuk analisis obyek yang ternaungi bayangan awan perlu dilakukan analisis tersendiri atau diulangi perekamannya dengan mempertimbangkan waktu perekaman yang berpotensi adanya awan (Imai et al. 2019).

Teknologi penginderaan jauh untuk kajian vegetasi dipengaruhi oleh nilai pantulan dari kanopi. Kanopi tanaman kelapa sawit yang terinfeksi penyakit BPB umumnya akan memberikan bentuk kanopi yang berbeda dengan tanaman yang sehat. Munculnya daun tombak lebih dari 3, daun patah, dan daun menguning akan menyebabkan nilai pantulan dari kanopi tanaman yang terinfeksi penyakit BPB dan tanaman sehat akan berbeda. Sedangkan karakteristik band kamera multispektral pada band merah dan hijau akan dimanfaatkan oleh daun untuk fotosintesis, sedangkan band inframerah dekat akan dipantulkan. Tanaman yang sehat akan mempunyai nilai pantulan band merah dan hijau yang lebih rendah dibandingkan dengan tanaman yang terinfeksi penyakit 
BPB. Karakter yang berbeda pada band inframerah dekat tanaman yang sehat akan memberikan nilai pantulan yang lebih tinggi dibandingkan dengan tanaman yang terinfeksi penyakit BPB. Karakteristik pantulan dari masing-masing band pada tanaman sehat dan terinfeksi penyakit BPB digunakan sebagai input variabel dalam machine learning RF untuk membangun model klasifikasinya ke dalam kelas tanaman sehat dan terinfeksi penyakit BPB.

Sebaran tanaman terinfeksi penyakit BSR menggunakan dua model yang didasarkan pada seluruh data pada areal yang ternaungi dan tidak ternaungi bayangan awan serta model yang dibangun menggunakan data pada areal yang tidak ternaungi bayangan awan menunjukkan perbedaan jumlah tanaman yang terinfeksi. Pada areal non bayangan awan jumlah tanaman yang terinfeksi penyakit BPB lebih sedikit pada model dengan menggunakan seluruh data dibandingkan dengan model yang dibangun dengan sebagian data pada areal yang tidak ternaungi bayangan awan. Hal yang berlawanan terjadi pada areal yang berada pada areal tertutup bayangan awan, model dengan sebagian data memberikan hasil klasifikasi tanaman terinfeksi yang lebih rendah dibandingkan dengan model dari seluruh data. Hal ini menunjukkan bahwa perbedaan model machine learning RF yang dibangun menggunakan data yang berbeda akan memberikan hasil yang berbeda jika diterapkan pada data yang sama.

Hasil dari penelitian ini menunjukkan bahwa identifikasi dan pemetaan sebaran tanaman kelapa sawit yang terinfeksi penyakit BPB dapat dilakukan salah satunya dengan memanfaatkan UAV dan kamera multispectral Mapir 3 band serta machine learning RF. Akuisisi data pada areal yang ternaungi bayangan awan dan tidak ternaungi bayangan awan perlu dilakukan kalibrasi pantulan secara terpisah. Hal tersebut dapat dilakukan dengan mengambil kalibrator pada areal di bawah bayangan awan dan non pengaruh bayangan awan kemudian kalibrator tersebut digunakan untuk konversi DN ke nilai pantulan pada areal yang sudah dibedakan areal yang terkena pengaruh bayangan awan dan non bayangan awan. Model juga harus dibangun didasarkan pada areal yang non dan terpengaruh bayangan awan, begitu juga untuk pemetaan penyebaran tanaman sehat dan terinfeksi penyakit BPB digunakan model yang dibangun sesuai dengan kondisi areal yang non dan terpengaruh bayangan awan. Selain itu, pengaruh tutupan bayangan awan dapat diminimalkan dengan melakukan pengamatan adanya awan sebelum pengambilan image (pemotretan) pada wilayah pemotretan. Pemotretan dapat ditunda jika dijumpai banyak terdapat awan dan hasil pemotretan akan dianalisis atau diklasifikasi berdasarkan nilai pantulan.

Akurasi klasifikasi tanaman yang sehat dan terinfeksi penyakit BPB dengan RF serta image dari UAV dan kamera multispektral Mapir (3 band) yang tertinggi sebesar $79.49 \%$ pada ukuran piksel $2.0 \times 2.0 \mathrm{~m}$. Akurasi $79.49 \%$ dengan pendekatan teknik penginderaan jauh masih dapat diterima menurut Sutanto (2010). Model RF yang dibangun dari sampel tanaman yang bebas dari bayangan awan mampu membedakan tanaman yang sehat sebanyak sebanyak 2294 (66.65\%) pohon dan tanaman yang terinfeksi penyakit BPB sebanyak 1148 (33.35\%) pohon. Peningkatan akurasi klasifikasi tanaman sehat dan terinfeksi penyakit BPB akan dilakukan pada penelitian lanjutan dengan memperhatikan waktu pemotretan, kondisi awan, dan berbagai tingkat serangan penyakit BPB (tinggi, sedang, dan rendah).

Peta sebaran tanaman kelapa sawit yang terinfeksi penyakit BPB akan memberikan arah bagi pengelola kebun dalam memberikan perlakuan-perlakuan kultur teknis untuk memperpanjang umur tanaman kelapa sawit yang terinfeksi penyakit BPB. Perlakuan kultur teknis tersebut dapat bermanfaat bagi tanaman kelapa sawit sehat agar tidak terinfeksi penyakit BPB. Perlakuan kultur teknis yang dapat dilakukan antara lain berupa pembedahan batang kelapa sawit yang busuk, pembumbunan batang kelapa sawit dengan tanah, dan pembuatan parit isolasi terhadap tanaman yang terinfeksi penyakit BPB dapat berguna untuk menghindari terjangkitnya 
tanaman kelapa sawit yang masih sehat (Priwiratama et al. 2014).

\section{UCAPAN TERIMAKASIH}

Ucapan terima kasih kami sampaikan kepada Pusat Penelitian Kelapa Sawit (PPKS) atas ijin dan dukungannya dalam melaksanakan penelitian ini, Madiyuanto sebagai pilot UAV dan mosaic image, serta Tim PPKS untuk pemetaan dan pengambilan data serangan penyakit BSR (Panca Agus, Muslim dan Nirwanto).

\section{DAFTAR PUSTAKA}

ENVI. 2014. ENVI Classic Help. Exelis Visual Information Solutions, Inc.

Hushiarian R, Yusof NA, Dutse SW. 2013. Detection and control of Ganoderma boninense: strategies and perspectives. Springerplus. 2:555. DOI: https://doi. org/10.1186/2193-1801-2-555.

Imai NN, Tommaselli AMG, Berveglieri A, Moriya EAS. 2019. Shadow detection in hyperspectral images acquired by UAV. Di dalam: International Archives of the Photogrammetry, Remote Sensing \& Spatial Information Sciences; 2019 June 10-14; Enschede (NL): ISPRS Geospatial Week. Volume XLII-2/W13. DOI: https:// doi.org/10.5194/isprs-archives-XLII2-W13-371-2019.

Lelong CCD, Roger JM, Brégand S, Dubertret F, Lanore M, Sitorus NA, Raharjo DA, Caliman JP. 2010. Evaluation of oil-palm fungal disease infestation with canopy hyperspectral reflectance data. Sensors. 10:734-747. DOI: https://doi.org/10.3390/ s100100734.

Liaghat S, Ehsani R, Mansor S, Shafri HZM, Meon S, Sankaran S, Azam SHMN. 2014. Early detection of basal stem rot disease (Ganoderma) in oil palms based on hyperspectral reflectance data using pattern recognition algorithms. Int J Remote Sens. 35:3427-3439. DOI: https://doi.org/10.10 80/01431161.2014.903353.
Ling-chie W, Bong CFJ, Idris AS. 2012. Ganoderma species associated with basal stem rot disease of oil palm. Am J Appl Sci. 9:879-885. DOI: https://doi.org/10.3844/ ajassp.2012.879.885.

Mc Cloy KR, Bøcher PK. 2007. Optimizing image resolution to maximize the accuracy of hard classification. Photogrammetric Engineering and Remote Sensing. 73(8):893-903. DOI: https://doi. org/10.14358/PERS.73.8.893.

Ming D, Yang J, Li L, Song Z. 2011. Modified ALV for selecting the optimal spatial resolution and its scale effect on image classification accuracy. Math Comput Modell. 54:1061-1068. DOI: https://doi. org/10.1016/j.mcm.2010.11.036.

Priwiratama H, Prasetyo AE, Susanto A. 2014. Pengendalian penyakit busuk pangkal batang kelapa sawit secara kultur teknis. J Fitopatol Indones. 10:1-7. DOI: https:// doi.org/10.14692/jfi.10.1.1.

Santoso H, Gunawan T, Jatmiko RH, Darmosarkoro W, Minasny B. 2011. Mapping and identifying basal stem rot disease in oil palms in North Sumatra with QuickBird imagery. Precis Agric. 12:233248. DOI: https://doi.org/10.1007/s11119010-9172-7.

Santoso H, Tani H, Wang X. 2017. Random forest classification model of basal stem rot disease caused by Ganoderma boninense in oil palm plantations. Int J Remote Sens. 38:4683-4699. DOI: https://doi.org/10.10 80/01431161.2017.1331474.

Santoso H, Tani H, Wang X, Prasetyo AE, Sonobe R. 2018. Classifying the severity of basal stem rot disease in oil palm plantations using WorldView-3 imagery and machine learning algorithms. Int $\mathrm{J}$ Remote Sens. 00:1-23. DOI: https://doi.or g/10.1080/01431161.2018.1541368.

Shafri HZM, Anuar MI, Seman IA, Noor NM. 2011. Spectral discrimination of healthy and Ganoderma infected oil palms from hyperspectral data. Int J Remote Sens. 32:37-41. DOI: https://doi.org/10.1080/01 431161.2010.519003. 
Shafri HZM, Hamdan N. 2009. Hyperspectral imagery for mapping disease infection in oil palm plantation using vegetation indices and red edge techniques. Am J Appl Sci. 6:1031-1035. DOI: https://doi. org/10.3844/ajassp.2009.1031.1035.

Susanto A, Prasetyo AE, Priwiratama H, Wening S, Surianto S. 2013. Ganoderma boninense penyebab penyakit busuk batang atas kelapa sawit. J Fitopatol Indones. 9:123-126. DOI: https://doi.org/10.14692/ jfi.9.4.123.

Sutanto 2010. Remote sensing research: a user's perspective. Ind J Geograp. 42(2):129-142.
Viera AJ, Garrett JM. 2005. Understanding interobserver agreement: the kappa statistic. Fam Med. 37:360-363. DOI:

Wiratmoko D, Prasetyo AE, Jatmiko RH, Yusuf MA, Rahutomo S. 2018. Identification of Ganoderma boninense infection levels on oil palm using vegetation index. Int J Oil Palm. 1:110-120.

Yao H, Qin R, Chen X. 2019. Unmanned aerial vehicle for remote sensing applications - A review. Remote Sensing. 11(12):1443. DOI: https://doi.org/10.3390/rs11121443. 